formula of the interpolator is 'In Hieremia,' \&c. ; that of St. Cyprian is 'Apud Hieremiam.'

Thus all the evidence converges irresistibly to the conclusion that these insertions, though worthy of being edited for the sake of therr Biblical text, are not Cyprianic, and are, therefore, not entitled to a place in the text of the Testimonia.

Before concluding it may be well to clear up a matter about which there appears to be some confusion.

At the beginning of his book Mercati enumerates the additions to Test. $\mathrm{i}$ I, I I, I3, I4 as belonging to the series characteristic of $\mathrm{W}$. This is an error. Test. $\mathbf{i} \mathbf{I}-\mathbf{I} 5$ are not preserved in $\mathrm{W}$ at all, so that we cannot say whether the preces in question were in that MS or not; but there is direct evidence that they do not belong to the series which forms the subject of this note :-(I) The history of their transmission is different : though absent from most of the MSS (from all those used by Hartel) they have a much wider diffusion than the interpolations in Test. iii, and found their way very early into the printed editions. (2) There are considerable differences between the text of Jer. xxxi 32-34 as given in Test. $\mathrm{i} I \mathrm{I}$ and in Test. iii 20 : in the former place we find 'neglexi eos' and 'dinosce,' in the latter 'neglexi eorum' and 'cognosce'; in Test. i $\mathrm{II}$ the words 'et in corda illorum' are omitted '; and again in Test. iii $20 \mathrm{~W}$ and Quir. agree in the curious reading 'et docebunt,' while in $i \mathrm{x}$ the ordinary reading 'et non docebunt' is found. (3) Finally the form of quotation from the prophets which $I$ have shown to be characteristic of the $W$ interpolations, is not used in the additions to Book i.

H. I. Ramsay.

\title{
ON THE DATE OF COMPOSITION OF THE PASCHAL CHRONICLE.
}

The Paschal Chronicle, otherwise called the Alexandrine or Constantinople Chronicle or the Fasti Siculi, consists of a tabular chronology with historical notices extending from Adam to 627 A.D. The Olympiads and consular lists are added in the text, and later on the Indictions. The compiler derives his matter from various sources, e.g., the Bible, Sextus Julus Africanus, Eusebius, Idatius (Hydatius in Mommsen's spelling), Epiphanius, Pseudo-Kallisthenes, Malalas, Acts of Martyrs. The whole work, as it is found in the best codex, Vaticanus Gr. 1941,

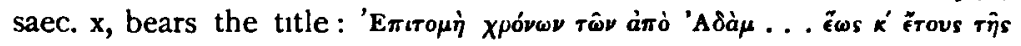

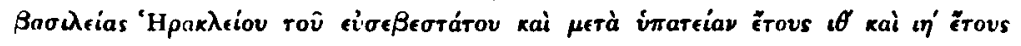

1 Mercati erroneously enumerates this omission as one of the imperfections of $W$ in il 20. W has the words there. 


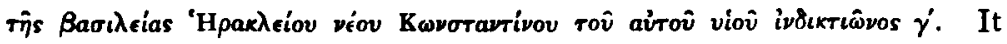
should, according to the above title, extend to A.D. 629, but in fact it is mutilated and ceases at the year 627 .

Ducange, in the preface to his edition (Paris 1688 , ch. $x$, page vini), wrote thus :-

Quoad igitur aetatem auctoris Chronici, cum non unus exstiterit a quo elucubratum fuerit, constat saltem illum, a quo ad Heraclium perductum est, non esse totius operis scriptorem, sed alterius qui in annum Constantii xvii, qui est Christi 354, desierit, continuatorem et interpolatorem. Id docemur praesertim ex doctissimi Holstenii obseruationibus, quas codıci suo Chronici Alexandrini edito subinde affixerat, hisce ad praedictum annum Constantii, post haec uerba ei $8 \hat{\omega} \boldsymbol{\nu}$ Aùyov́rtov, adscriptis : 'Hic desiit auctor Chronici Paschalis, caetera sunt Continuatoris.' Id certe subodoratus fuerat uir admodum sagax Franciscus Pithoeus, qui de hoc Chronico uerba faciens, aiebat illud uideri scriptum ultimo Magni Constantini anno, Feliciano et Tatiano Coss. Inde ergo colligitur primum auctorem Paschalıi u1xisse circa tempora Constantii, quibus adhuc uigebant de Paschalis Festiuitatis die controuersiae : quae cum recruduissent sub Heraclio, ut infra obseruamus, occasionem alteri praebuerint Paschale istud Chronicon pridem conscriptum, Scriptoris insistendo computisticae rationi, ad sua usque tempora perducendi, atque adeo prorem hanc editionem subinde interpolandı, dum sua uel aliena intermiscet. Prius istud Chronicon uidit Holstenius, et, quantum conicere licet, ex codice MS quem, ut ex V.C. Emerico Bigotio didicimus, Abbas de Farina Siculus Regi Catholico ab Oratorio Constantınopoli comparauerat, ipsique communicauerat. Illud deinde cum editione Raderiana idem Holstenius contulit, uariis ad margines adscriptis coniecturis: ubi quae subinde erant inserta $\mathrm{ab}$ interpolatore, deerantque in eodem MS exemplari diligenter adnotauit. Quinetiam in reliqua deinceps Chronicı parte emendationes ex ingenio adıecit. Quae quidem omnia in Notas nostras retulimus, eique, ut par est, adscripsımus, tum ne alıum dicamur suppilasse, tum quod urri undequaque doctissimi in re literaria adepta pridem existimatio et auctontas Lectorem in illius sententiam haud aegre forte adduxerit.

From the above we learn that the codex of Holstein (or Holsten, or more properly Holst), a German scholar who was the Pope's librarian from 1636 to his death in 1661 , contained a shorter and earlier form of the Chronicle, reaching only to the year 354 , and omittıng some matter, even before that date, which is found in the longer form printed in Raderus' edition, Munich, 1615. A chronicle compiled in or about 354 must be more reliable for the period then ending than one compled in 630. Also if such a chronicle has matter in common with Malalas,

VOL II. 
Epiphanius, and other writers subsequent to $35^{\circ}$, it cannot have derived it from them; either they derived from it, or both from common sources.

Holstein's good faith, however, has been impugned; the very existence of the codex, of which Ducange prints a collation in his notes to the Chronicon, has been denied, and it is asserted that the great French scholar was simply hoaxed by Holstein. Professor Gelzer writes as follows in his book entitled Sextus Julius Africanus und die Byzantinische Chronographie, Leipzig, 1885, pt. 2, p. 139 :-

' Der Bearbeiter der Chronik unter Herakleios soll nur der Continuator eines viel altern Werkes sein. Lucas Holstenius, "quantum coniicere licet," wie Du Cange vorsichtigerweise bemerkt, will einen Codex gesehen haben, welcher aus Constantinopel stammt und S. $54 \mathrm{I}, \mathrm{I} 3 \mathrm{mit}$

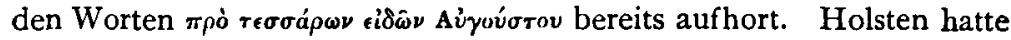
die Varianten, vermehrt durch eigne Verbesserungen, am Rande einer Raderschen Ausgabe angemerkt . . .'

Gelzer then reviews the pros and cons, and concludes as follows, p. I4I: 'Ich wage nicht, auf dieses hin die Wahrhaftigkeit des Holstenius so weit anzuzweifeln, dass ich uberhaupt die Existenz jenes von ihm benutzten Codex des Abbate Farina leugne. Aber jedenfalls beruht das, worauf der Hauptwerth der Holstenschen Mittheilungen beruht, die Angaben uber das Fehlen der eine spätere Epoche beweisenden Citate, lediglich auf Conjectur des gelehrten Mannes. Die Stucke fehlen, welche er nach seinem Wissen fur sicher spater hielt, und welche sich mit guter Manier ausscheiden liessen. Die Stucke, welche ebenso sicher nach 354 concipirt sind, denen er aber diesen Ursprung nicht anmerkte, blieben unbeanstandet. Ich glaube demnach, dass die ältere Redactıon der Chronık unter Constantius sich in nichts auflost.'

Surely this critic might go the whole way, and declare that Holstein concocted not merely the collation, but the codex as well.

Gelzer's conclusions have been accepted in turn by Carolus Frick, who, accordingly, in the Byzantinische Zeitschrift, Vol. I, Part 2, 1892, assumes Malalas to have been the 'bevorzugte Quelle' of the Paschalion as much in its earlier as in its later portions : by G. Kruger in the Artıcle on Chronicon Paschale in the new edition (Leipzig 1898) of Herzog's Realencyclopadie fur Theologie und Kirche: by Karl Krumbacher, Byzantinische Litteraturgeschichte, Munchen, I897, § 142, who writes: 'Die fruher verbrettete Annahme einer älteren Redaction unter Kaiser Constantius .... ist durch Gelzer's tiefgehende Untersuchungen hınfallig geworden': by Prof. J. B. Bury (as it would seem), Ed. of Gubbon, Vol. v 497, London 1898, also ii 539 : and finally by Mommsen, who remarks in his edition of the Chronica Minora, Berol. 
1881, tom. ix of the Monumenta Germaniae Historica, p. 203 : 'Chronicon Paschale quod appellari solet ... prodist anno, ut titulus ait, p. Chr. 630 Constantinopoli : nam quae fertur facta esse a. 354 editio prior, eam nullam esse uiri docti hodie consentiunt.'

Perhaps it is excusable to mention how my own attention was drawn to this problem. In editing the dialogue of Timothy and Aquila, I was led to compare the account given in it of the apostasy and hermeneutic activity of Aquila with the parallel passages of Epiphanius and the Paschal Chronicle. I found that the latter contains certain well-marked variants from the text of Epiphanius, and that several of these variants recur in the Dialogue. I drew the only possible inference, namely that the Chronicle and the Dialogue drew their matter not from Epiphanius, but from some common source which Epiphanius also used. But then the paragraph of the Chronicle ends with the words ravira ioropei

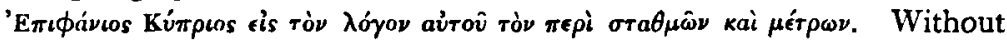
having heard of Holstein's codex, I conjectured that this reference to Epiphanius must be an interpolation; and on consulting Ducange's notes, I found that Holstein's codex omitted it. I surmised in consequence that Holstein's good faith and Ducange's good sense had been wrongly assailed, and set myself on reaching Rome in the April of 1900 to look for the Codex Holstenii in the Barberini and Vatican libraries. In the former there are several entries in the MS catalogue that suggest it, but they all proved illusive. In the Vatican there was no trace of it, and Father Ehrle and Dr. Mercati, whose unfalling solicitude for students makes their library doubly charming as a place of research, assured me that so large a Greek codex could not have escaped notice. Incidentally, however, I learned much at Rome about Lucas Holstein. I turned over many of his transcripts, and realised from them how sincere and honest a scholar he was. A young French archaeologist, M. de Ricci, also engaged upon Holstein's manuscripts, agreed with me in this opinion, and Dr. Ehrle ', no mean authority, merely smiled at the stigma so lightly set by Mommsen and the viri docti on the memory of his great predecessor.

Returning to Oxford, I set myself to find out, if I could, what Bigot, the great French bibliophile and patron of learning in the seventeenth century, knew of the codex; and opening M. Delisle's monograph upon Bigot and his library, I lit on a letter of the great collector which clears up the matter. M. Delisle's volume is rare, for its issue was limited to forty copies. I therefore cite at length the relevant pages.

1 Dr. Ehrle drew my attention to an article in the Centralblatt fur Bibliothekswesen by Hartwig (Leipzig, Oct I 895) on the MSS bequeathed by Holstein to his native city of Hamburg. No codex of the Chronicon Paschale figures among them. and indeed this particular codex was not Holstein's but belonged to the Spanish kıng. 
From the 'Bibliotheca Bigotiana Manuscripta' par L. Delisle, Rouen, Henry Boissel, 1877 , p. xini : 'Mais ce qui achève de peindre les gouts studieux et le désintéressement de Bigot, c'est la lettre dans laquelle 1 entretient Du Cange de ses travaux sur le Chronicon Alexandrinum. Pendant les loisirs qu'il avait eus dans les hôtelleries d'Allemagne, il s'était amusé à corriger la version latine de cette chronique dans un exemplaıre qu'll avait spécialement fait relier pour ce travail. De son côté, Holstenius avait commencé à revoir la même version et à collationner le texte grec sur le manuscrit original qui lui appartenait. Quand Bigot vint à Rome, Holstenius ne se contenta pas de lui donner communication de son travail; il le chargea de le terminer et de l'emporter en France pour le comprendre dans la collection des historiens byzantins. De retour à Paris, Bigot confie à Thoinard l'exemplaire du Chronicon Alexandrinum qu'il rapportait d'Italie et celui sur lequel il avait travaillé en Allemagne. Thoinard garda ces volumes pendant plusieurs années, différant d'en commencer l'impression et éludant les trop justes réclamations de Bigot. Ce dernier avait à peu près oublié cette affaire quand il apprend que Du Cange prépare une nouvelle édition dı Chronicon Alexandrinum . . . Loin d'être contrarié par cette nouvelle, Bigot ne songe qu'aux moyens de faciliter la tâche de son ami : il ne pense pas un instant à l'édition dont il avart, de concert avec Holstenius, réuni tous les éléments. La singulière conduite de Thoinard ne lui arrache pas même un mot amer; ll n'a qu'un désir, celuı de recouvrer ses anciens travaux pour les mettre sans réserve à la disposition de Du Cange. Je me ferais une reproche de retrancher un mot à la lettre (Fonds français, Bibl. Nat. 95०3, fol. 5) dans laquelle sont rapportées toutes ces particularités.'

The letter which follows is dated Rouen, April 28, r684: 'Monsieur, Ce m'a esté une grande joye, à mon arrivée en cette ville, de reçevoir vostre lettre, qui m'a appris vostre dessein de faire rimprimer le Chronicon Alexandrinum. Je vous assure que je serois ravi d'y pouvoir contribuer quelque chose, et je l'aurois pu si j'avors à mon pouvorr et à ma disposition les deux exemplaires de cette chronique que j'ay prestés et confiés à M. Thoinard.

'A mon voiage d'Allemagne, je rencontré un exemplarre de cette chronique en blanc, que je fis relier et que je lisois de temps en temps quand j'estois arrivé au logis et que je n'avois point d'autre occupation. Je corrigé à ce temps là la traduction en quantité de passages.

'Estant à Rome, M. Holstein me dit qu'll avait l'original de cette chronique, que l'abbate della Farina, Sicilien, avoıt apporté de Sicile à Rome, que cet exemplaire avoit esté apporté à Messıne par un marchande de Constantinople, et que ce chronıque devoit estre appellé Chronicon Constantinopolitanum, ayant esté composé à Constantınople 
et par un citoien de cette ville là, parce que l'autheur, parlant des affaires

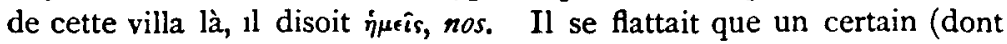
je ne me souviens plus du nom présentement, je l'ay indıqué à M. Thoinard) avoit escrit Chronicon ualde pium, ce qu'll interpretoit de cette chronıque, qui avoit esté composée princıpalement pour marquer les jours des Pasques, et que pour cet effect il avoit mis à la teste de sa chronique plusieurs extraits des anciens qui reguardoient la Pasque, qui se trouvent dans le ms. et non dans l'édition de Raderus. M. l'abbé de la Farina presta ce ms. à M. Holstein, qui transcrıvit ces traités qui sont au devant de cette chronique qui regardent la Pasque, et conféra une partie de la chronique. N'ayant pu achever à la conférer à cause de son infirmité, ll me pria de continuer de la conférer, me disant qu'il vouloit me baller cet exemplaire pour porter en France, affin de le faire imprimer au Louvre comme fassant partie de l'histoire byzantine. J'entrepris cette collation et je l'achevé deux jours devant sa mort '. L'ayant achevée, je remis le ms. entre les mains de l'aumosnier de M. Holsteın, et je le prié de luy dire que j’avois achevé de conférer ce ms. que je lui renvoiois, et que je gardois son exemplaire pour le porter en France, affin que, si M. Holstein mouroit et que l'on eust sceu que j'eusse eu cet exemplaire, on ne creust point que je le voulusse retenir et me l'approprer. M. Holstein dit à son aumosnier qu'll me proit de le prendre, de le porter en France et de le faire imprimer au Louvre. Après la mort de M. Holstein, j'eu parlé à M. le cardinal Barberin, qui sçavoit bien que M. Holstein m'avoit confié cet exemplaire. L'original doit avoir esté mis dans la bibliothèque du Vatican: pour le moins, c'estoit l'intention de M. Holstein. S'll n'y est point, ll doit estre dans celle de M. le cardinal Barberın, qui estort exécuteur du testament de M. Holstein et légataire unıversel. J'ai baillé à M. Thoinard cet exemplaire, qui contıent les diverses leçons du ms. grec, et de plus la correctıon de la traduction qu'avoit faite M. Holsteın. C'estoit l'original de M. Holstein, et s1 M. Thoinard ne veut point rebailler cet exemplarre, on ne peut pas avoir cette correction de la traduction.

' Je ne sçai quel conseil vous donner à l'égard de $M$. Thoinard. Il y a quelques années que je lui redemandé ces deux exemplarres ... Il (sc. Thoinard) me dit de plus qu'll avoit escrit sur ces deux exemplaires. Je luy répliqué pourquoy il y avoıt écrit, ne luı appartenant pas. Pour vous parler franchement, je n'en eus pas grande satısfaction. Je croi pourtant que l'on pourroit luy en reparler, et sçavoir présentement son sentiment, s'll vouloit baller ces deux exemplaires ou qu'll souffre que l'on copie les corrections du texte grec et de la traduction. Si M. Fromentin (?) est à Paris, ll pourroit luy en escrire, ou bien, si vous voulez, je luy en escrirois. Il me semble qu'll ne devroit pas refuser de

1 Holstenius died Feb. 2, 166I. 
communiquer ces exemplaires. S'il veut, on imprimera ses remarques sur cette chronique et ses observations sur la pasque.'

The above letter proves beyond debate the following :-

I. That the Codex Holstenius was brought from Constantinople by a merchant, ex oratorio says Ducange, so revealing some further knowledge of its provenance than Bigot's letter conveys.

2. It was brought to Sicily to Messina, whence so many codices have come. From Messina the Abbate della Farina brought it to Rome, having bought it for the Catholic king. In the Bodleian copy of Raderus' edition is a note on p. 54 (in the hand it would seem of Bishop Barlow of Lincoln) against the words $i \pi i$ oiv, as follows :-

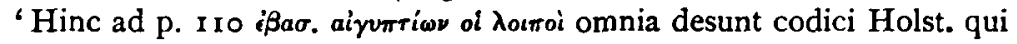
pertinuit ad regem Hispaniarum Bigotio referente.' Perhaps Barlow had independent knowledge of the codex, and had, in the course of a visit to Bigot's library at Rouen, seen the collation of it. In the margin of this Bodleian copy is given a collation of Holstein's codexapparently, but not certainly, transcribed from Ducange's notes.

3. The abbate lent this codex to Holstein who collated the first part of the text. Bigot completed the collation in Holstein's copy of Raderus' edition, restored the MS to Holstein just before the latter's death, and brought the collation to Rouen in $166 \mathrm{r}$. Then he lent it to Thoinard, who, 23 years later, April, I684, still kept it. From Thoinard Ducange must have obtained it in time for his edition of 1688 .

4. The author of the Chronicon set at the head of it many Paschal extracts not contained in Raderus. One would like to know what became of these; for Ducange seems to have known nothing of them, although Holstein transcribed them. They probably lurk in the Barberini collection, and would be a valuable addition to the early literature of the Easter controversy.

This letter is in itself adequate to recall this constellation of viri docti from the eccentricities of rash hypothesis into the soberer orbit of historical method. It makes it superfluous for me to print the extended examination of the Chronicon which I had prepared with a view to demonstrate from its internal evidence the reality of Holstein's codex. Still there are two or three features of the Chronicon and its continuator which deserve notice.

Of these the first is the Arian complexion of the Chronicon in its earlier and shorter form. Thus on p. 270 (ed. Ducange) Leontius, the Arian bishop of Antioch, is styled $\delta$ paxáaos, and his account of St. Babylas is quoted. On p. 289 the same Leontius is singled out for eulogy as 'a man in every way full of faith and reverence, as an enthusiast for the true faith, full of solicitude for the hostels,' and so 
forth. Gelzer supposes that this eulogy is taken over by the seventh century compiler of the Chronicle from an older work written by an Arian, and he writes thus: 'So kann von dem Zeitgenossen des Constantius nur ein Arianer der folgenden Generation schreiben : kein Orthodoxer des 7. Jahrhunderts.' But is it likely that a seventh century orthodox author would ever have gone out of his way to insert such a passage in his work? A mere continuator might forget to strike it out, but no one compiling for the first time in 630 would have deliberately chosen such an eulogy to stand in his record of events. Some have argued that the compiler drew upon Philostorgius, as if there were not plenty of other Arian historians in the fourth century, whose works are lost to us ${ }^{1}$.

No reason is urged by Prof. Gelzer why Holstein should have pitched upon the year 354 for the termination of his imaginary chronicle, but there must be some connexion here with the 'Fragmentum Fastorum ab anno Christi ccv ad annum cCcLIv' added by Ducange in his fifteenth appendix, and with the old list of consuls and prefects from 254 to 354 given in his sixteenth. The old Latin Chronicle nicknamed the Barbarus Scaligeri has, as Frick (Chronica Minora, Lipsiae, I893, p. civ) points out, the same mispellings of names as the Paschal

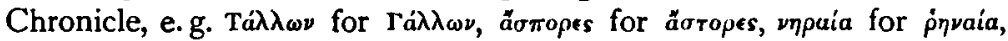

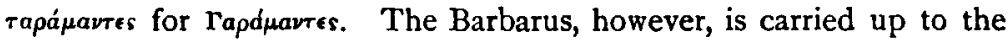
year $3^{8}$, but I should conjecture that the earher form of the Paschal Chronicle is its original up to the year 354 .

There are other features about Holstein's Codex and the collation of it, which might have put scholars on their guard and made them more chary of fixing on Holstein the stigma of charlatanry. For example, why should Holstein have been so careful to distinguish in the margin of his copy of Raderus his own conjectures from the variants of the Codex? 'Varias lectiones et coniecturas eruditissimi Holstenii subinde inseruimus,' writes Ducange (Praefatio, p. xc). Again in fabricating a collation he would surely have limited himself to cuttıng out of the text (as Gelzer suggests) what was incompatible with a later date than 354. But instead of doing so he often corrects the text of Raderus from his Codex, and in most cases rightly. A cursory glance through the collation will convince any reader that, if he had no real Codex to

1 It may be noted in passing that Conrad Gesner (Bibliotheca Untversalis, ed. I 545, p 56I) relates that he saw a Greek codex of parts of Philostorgius' history in the library of Diego Hurtad, the Spanısh kıng's legate at Venice. In the catalogue of Bigot's library (sold at Paris in July, 1706 ), No. 3040 is a copy of Philostorgius' $C \mathrm{~km}$ notis inscr. D. Bigotsi. These notes probably contained valuable matter, as may also No. $3^{113}$ of the 'Fonds grec' of the Bibliotheque Nationale, which belongs to the 'Collectanea Bigotiana,' and has p. 97 foll. the 'Notae Lucae Holstenil in Historiam Phılostorgii." 
go upon, then he was the most consummate critic the world has ever seen. Again and again in Ducange's Commentary we have such notes as these: 'Reposuimus et emendauimus ex cod. Holstenii' (p. 49c); 'Hanc uocem delet cod. Holstenii, et delendam docet numerus $\boldsymbol{\beta}^{\prime}$ praefixus' (p. 72 A); 'Haec ex Holstenio suppleuimus' (p. 186 D): 'Haec iure delet cod. Holstenii' (p. $216 \mathrm{c}$ ) ; 'Iure 1gitur totam hanc periochen omittit codex Holstenii' (p. 255 D). If it was the cue of Holstein merely to omit passages incompatible with the hypothesis that the Chronicle was first compled up to 350 , then why should he have pretended that his codex omitted excerpts compatıble with his assumed date, such as the

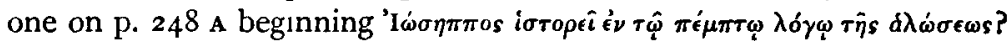
Surely the imaginary compiler of A.D. 354 might be allowed to retain his Josephus extracts! And the exigencies of his theory must have pressed heavily on Prof. Gelzer, when he wrote the following: 'Malalas war zu Holsten's Zeit noch nicht edirt. Allerdings fehlt das grosse Excerpt im Beginn S. 64-86 (ed. Bonn) : ich vermuthe aber fast wegen der Citirung von Cyrillus contra Iulıanum.' Now this reference to Cyril comes at the very end of a passage extending over eleven pages of the Bonn edition and over twelve of that of Ducange. It refers also not to the entire passage, but to a citation (incidentally introduced near the end of $1 t$ ) of Hermes Trismegistus. The latter is declared to have lived

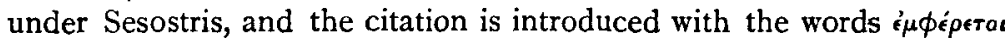

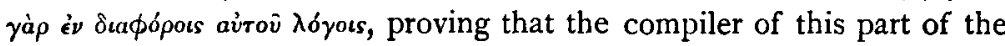
Chronicon used the works of Hermes as his source. After the citation

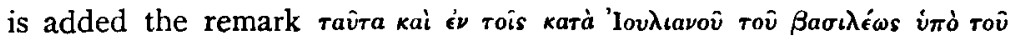

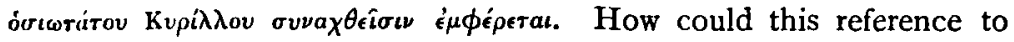
Cyril added at the end of a passage filling so many pages have led Holstein to excise them all? Surely he would have been content to cut out the name of Cyril, as on p. $255 \mathrm{C}$ he merely cut out (according to

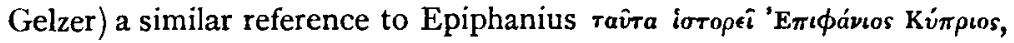
although leaving intact the passage taken from Epiphanius. Now the pages 64-86 (ed. Bonn), omitted in Holstein's codex, are, as Gelzer remarks, a gigantic loan from Malalas, whose chronicle, first edited at Oxford from the unique Bodley MS in $169 \mathrm{r}$, was unknown to Holstein, who, if Gelzer's hypothesis is to be accepted, must be held to have suffered from clairvoyance.

In the presence of Bigot's letter, however, argument ceases. Soluuntur tabulae. I have adduced these considerations merely by way of pointing out how rash it is to charge the learned men of the past with charlatanry, without having well and deeply weighed one's reasons.

A few remarks in conclusion as to the likelihood of Holstein's codex being actually found. Its connexion with the 'Catholic king' points to Naples or Madrid as the likeliest places to look for it in. In the Naples 
catalogue however there is no trace of it ; and Mommsen's contention (Mon. German. hist. Auct. Antiq. t. ix, p. I S 86) that the Escurial codex burned in $167 \mathrm{I}$ was a copy of the existing Vatican codex seems to be well grounded.

The following entries in the MS catalogue of the Vatican library refer to Greek Chronicles of the Byzantine Age :-

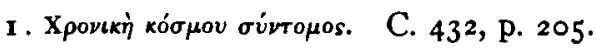

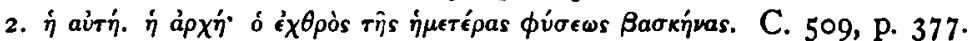

3. X

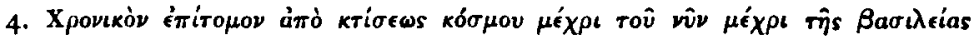

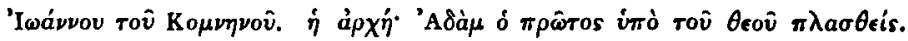
C. 433 , p. 244 ; C. 840 , p. 2 I 7 .

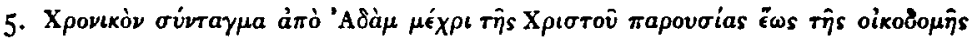

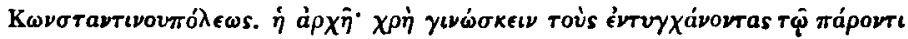

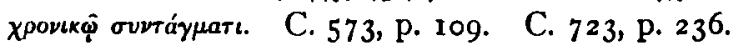

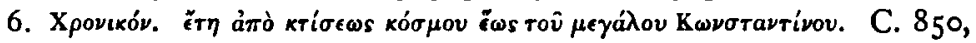
p. $25^{8}$.

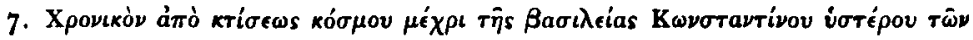
$\pi a \lambda a c o \lambda o ́ \gamma \omega \nu . \quad$ C. 162, p. 72.

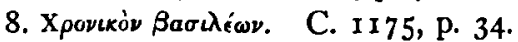

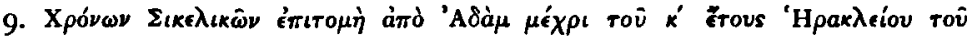

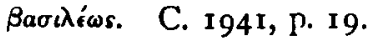

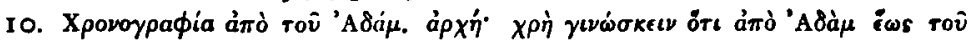

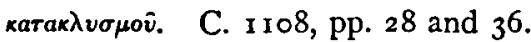

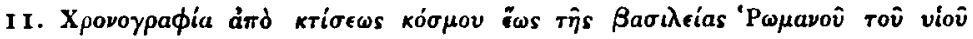

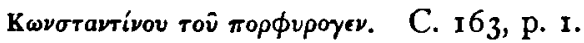

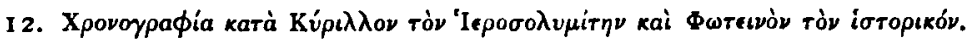
C. 197, p. 121 .

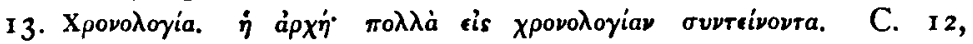
p. 204.

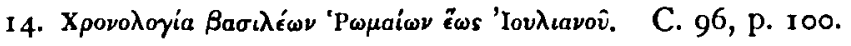

Of the above No. 9 is the tenth-cent. codex of the Chronicon Paschale: No. 12 must be the work ascribed to Cyril of Alexandria (see Krumbacher, $\S_{150}$ ); Photeinos may be the hagiographer mentioned by the same authority $\S 8_{3}$ : No. I 4 covers the same ground as the last part of Holstein's codex, but is not the same.

It 1s, however, possible that the codex may still lurk in the Barberini collection, which is badly catalogued and certainly contains many treasures of which its curators know nothing.

In the catalogue of Bigot's library already referred to, and of which the Bodleian has a copy, No. $299^{2}$ is a copy of Raderus' edition of the Paschal Chronicle. It probably had in the margin Bigot's collation of 
Holstein's codex, but as the collection of Bigot's printed books was dispersed, it would not be easy to find it to-day. In the 'Fonds français' of the Bibliothèque Nationale, No. 9467 , among Ducange's papers, are preserved the 'Chronici Alexandrini Collationes'(see Omont, 'Inventaire des mss. grecs,' Paris, I 888 , pt. 3, p. 389). In these, if anywhere, further information would be found to supplement what $I$ have been able to put together in the above pages.

\section{F. C. Conybeare.}

\section{DIFFICULTIES IN THE TEXT OF THE GOSPELS EXPLAINED FROM THE ARAMAIC.}

I. In St. Mark xii 3, 4, we are told that the wicked husbandmen 'beat and sent away empty' the first messenger of the absent owner of the vineyard, and 'wounded in the head,' and 'shamefully handled,' the

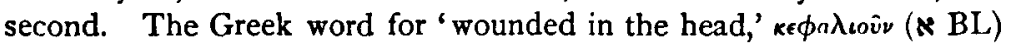
presents us with a difficulty. In the first place it occurs only here. And secondly, if the meaning 'wound in the head' could be supported, so particular a word would still be surprising. Why the head? If the narrative were a relation of fact we should accept the statement with a sigh of pity for the ill-used envoy; but in a parable we expect some more general and less anatomical expression parallel to the comprehensive verbs of the context, 'beat,' 'shamefully handled,' 'killed.' Now to those who believe that the Lord was accustomed to speak in Aramaic, it will seem natural to suppose that the Greek word here used represents or misrepresents an Aramaic verb, which it may or may not be possible to rediscover.

I wish to suggest that we can go further than this, and find some ground for supposing that the writer is not merely putting into Greek, or recording in Greek, words spoken in Aramaic, but that he has before him in writing an Aramaic word which he has misunderstood. In other words he was translating an Aramaic document. There is a common Aramaic and Syriac root באש, which in the Aphel means to 'misuse,' 'maltreat,' 'afflict.' The following examples from the Targums and Syriac VSS will illustrate its usage :-

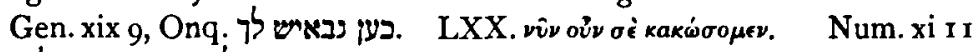

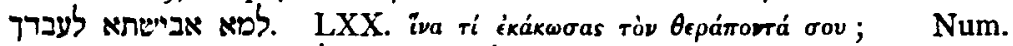

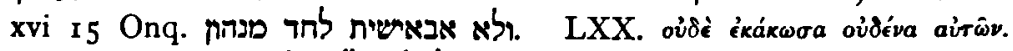

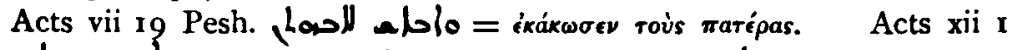

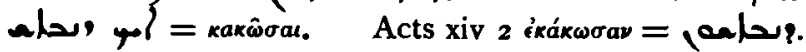

Now it is, I think, plain that the meaning of this verb vax = kaxoiv 